\title{
Innovations in Curriculum Designs Do Not Guarantee Students' Patient-Centered Attitudes Running Title: Curricula and Patient-Centered Attitudes
}

\author{
Inovações no Desenho Curricular não \\ Garantem Atitudes Centradas no Paciente \\ entre os Estudantes
}

\author{
Claudia Maria Alves da Silva PereiraIథ \\ Filipe Miranda Bernardes \\ Amanda Giroldo Minari ${ }^{I}$ \\ Carlos Henrique Martins da Silva ${ }^{I}$ \\ Helena Borges Martins da Silva Paro
}

\section{KEY-WORDS \\ - Physician-Patient Relations. \\ - Curriculum. \\ - Attitude.}

\begin{abstract}
Background: Medical schools all around the world are engaged in curricular reforms aimed at fostering patient- and learner-centeredness, implementing curricular transformations in order to counterbalance the erosion of humanistic and professional values and the loss of idealism of recent graduate physicians. In Brazil, medical schools are facing the challenge of redesigning medical curricula towards more learner-centered and patient-centered approaches, stimulated by recent national medical education guidelines. However, desirable outcomes towards medical education have not been fully achieved. Aim: To access medical students' attitudes and determine predictors of medical students' patient-centered attitudes among students from different curricular designs (traditional, innovative and advanced). Methods: Medical students from 1st to 6th year from 21 Brazilian medical schools participating in the project for evaluating change and trends proposed by the Brazilian Association of Medical Education, with different stages of curricular designs (traditional, innovative and advanced), answered the Brazilian version of the Patient-Practitioner Orientation Scale (B-PPOS) and a questionnaire with curricular and sociodemographic variables. Results: Brazilian medical students care more than they share information, power and responsibility $(p<0.001 ; d=0.599)$. They are more concerned with the psychosocial context than with patient's perspective $(p<0.001 ; d=0.797)$ and share more power and responsibility than understanding $(p<0.001, d=0.455)$. Female gender ( $B=$ $0.180)$, students from public schools $(B=0.132)$, year of medical training $(B=0.021)$, preference for future medical practice in public services $(B=0.053)$ and extracurricular activities $(B=0.068)$ were predictors of patient-centered attitudes among medical students $(p<0.05)$. Meanwhile, the father's educational level and choice to study surgical specialties $(p<0.05)$ were predictors of less patientcentered attitudes among students. Different curricular designs were not associated with students' patient-centered attitudes $(p>0.05)$. Conclusions: Curricular designs did not predict medical students' attitudes. Being female and going to a public medical school were important predictors of patient-centered attitudes among medical students. Further research should investigate the direct influence of faculty professionalism development programs on students' patient centered-attitudes.
\end{abstract}

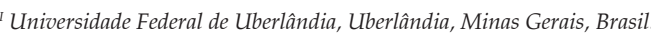




\section{PALAVRAS-CHAVE}

- Relações Médico-Paciente.

- Currículo.

- Atitude.
Introdução: Escolas médicas de todo o mundo estão engajadas em reformas curriculares com o objetivo de melhorar a centralidade do ensino no paciente e no aluno, implementando transformações curriculares a fim de contrabalançar a erosão dos valores humanísticos e profissionais, bem como a perda do idealismo de médicos recém-formados. Escolas médicas brasileiras encaram o desafio de redesenhar os currículos médicos em direção a abordagens mais centradas no paciente e no aluno, estimuladas pelas recentes diretrizes curriculares nacionais dos cursos de Medicina. Entretanto, os resultados desejados não têm sido totalmente alcançados. Objetivo: Acessar as atitudes dos estudantes de Medicina e determinar preditores das atitudes mais centradas no paciente entre os estudantes de Medicina de diferentes desenhos de currículo (tradicional, inovador e avançado). Método: Estudantes de Medicina do primeiro ao sexto ano de 21 escolas médicas brasileiras que participaram do projeto de avaliação de tendências de mudanças no curso de graduação nas escolas médicas brasileiras proposta pela Associação Brasileira de Educação Médica, com diferentes estágios de currículo (tradicional, inovador e avançado), responderam à versão brasileira da Escala de Orientação Médico-Paciente (EOMP) e a um questionário com variáveis sociodemográficas e curriculares. Resultados: Estudantes de Medicina brasileiros cuidam mais do que compartilham informação, poder e responsabilidade $(p<0.001 ; d=$ 0.599). Cuidam mais do contexto psicossocial do que da perspectiva do paciente $(p<0.001 ; d=0.797)$ e compartilham mais poder e responsabilidade do que entendimento $(p<0.001, d=0.455)$. Gênero feminino $(B=0.180)$, estudantes de escolas médicas públicas $(B=0.132)$, ano de treinamento médico $(B=0.021)$, preferência por futura prática em serviços públicos $(B=0.053)$ e atividades extracurriculares $(B=0.068)$ foram preditores de atitudes mais centradas no paciente entre os estudantes de Medicina $(p<0.05)$. Diferentes desenhos curriculares não foram associados com atitudes mais centradas no paciente $(p>0.05)$. Conclusões: Desenhos curriculares não predizem atitudes dos estudantes de Medicina. Ser mulher e frequentar uma escola médica pública foram importantes preditores de atitudes mais centradas no paciente entre os estudantes de Medicina.

Recebido em: 15/2/19

Aceito em: 7/5/19

\section{INTRODUCTION}

In recent years, medical schools have engaged in curricular reforms aimed at fostering patient- and learner-centeredness ${ }^{1,2,3}$. Such curricular transformations are thought to counterbalance the erosion of humanistic and professional values ${ }^{4}$ and the loss of idealism ${ }^{5}$ of recently-graduated physicians. Innovations usually involve faculty, students and institutions acting as the modeling process of relationship-centered professional values $^{6,1}$.

Despite attempts for curricular change, desirable outcomes towards patient-centered care have not been fully analyzed $^{7,8,3}$. Most studies have assessed punctual interventions in the medical curriculum, addressing longitudinal integrated clerkship $^{2,9}$ and integrated communication skills activities ${ }^{10,11}$. However, previous results of the real effects of curricular designs on medical students' attitudes are controversial ${ }^{12,5}$.

In line with this trend, Brazilian medical schools are facing the challenge of redesigning medical curricula towards more learner-centered and patient-centered approaches, stimulated by recent national medical education guidelines ${ }^{13}$. Since the publication of these educational guidelines, Brazilian schools have been involved in different stages of curricular changes. This multicenter cross-sectional study aims at assessing medical students' attitudes and predictors of patient-centered relationship among different curricular designs (traditional, innovative and advanced).

\section{METHODS}

\section{Setting and study population}

All medical students enrolled at the medical schools participating in the project for evaluating change and trends proposed by the Brazilian Association of Medical Education were invited to this cross-sectional study.

This national project consisted of the completion of a self-evaluation instrument designed to detect different stages of curricular changes by each academic community (students, faculty and preceptors $)^{13}$. Based on this self-evaluation, medical schools may be classified into three categories of curricular 
design: traditional (predominance of teacher- and disease-centered approaches), innovative (with characteristics of both traditional and advanced education) and advanced (predominance of learner-centered and system-based approaches) ${ }^{14}$.

The institutional review board at each of the 21 participating medical schools approved the study prior to student recruitment. An online website-platform was used for data collection from August 2015 to March 2016. After signing informed consent forms, 1,463 medical students from the $1^{\text {st }}$ to $6^{\text {th }}$ year answered two online instruments: the Brazilian version of the Patient-Practitioner Orientation Scale (B-PPOS) and a questionnaire with sociodemographic and curricular variables.

\section{Study instruments}

We used the B-PPOS to assess medical students' attitudes towards the doctor-patient relationship. The scale contains two 9-item domains: Caring and Sharing. Answers were given in a six-point Likert scale $(1=$ strongly agree to $6=$ strongly disagree). Based on previous studies with the original PPOS, students' attitudes could be classified as patient-centered (score $\geq 5.00)$, moderately patient-centered $(4.57<$ score $<5.00)$ and doctor-centered (score $\leq 4.57)^{15}$. The domains were divided into four subscales: caring - the patient's perspective and the psychosocial context; and sharing - sharing understanding and sharing power and responsibility ${ }^{16,17}$.

We used a questionnaire with sociodemographic and curricular variables to assess students' age, gender, father's and mother's educational level, religion and religious involvement, future medical service (public/private), participation in extracurricular activities, future area of specialization (clinical/surgical) and year of medical training. We also assessed school administration (public/private), school self-evaluation of curricular design, presence and duration of communication skills activities in the curricular syllabus.

\section{Statistical analysis}

We used descriptive statistics and chi-square tests to compare sociodemographic and curricular characteristics. We predicted the influence of sociodemographic and curricular variables in B-PPOS scores with Ordinary Least Squares Regression Analysis. We included only variables with significant Spearman's correlation coefficients with the B-PPOS scores in regression models. P-values lower than .05 were significant.

A minimum of 374 medical students was needed to detect a medium effect size ${ }^{18}$. We used Cliff's delta (d) values to calculate effect sizes and they were interpreted as follows: negligible $(\mathrm{d}<0.147)$, small $(\mathrm{d}<0.330)$, medium $(\mathrm{d}<0.474)$ and large effects $(\mathrm{d} \geq 0.474)^{19}$. We used IBM SPSS Statistics (version
21), Gretl (version, 1.9) and Cliff's Delta Calculation software for our analyses.

\section{RESULTS}

Medical students' mean age was 22.3 years $(\mathrm{SD}=3.3)$, most of them being female $(n=867 ; 59.3 \%)$. Table 1 shows students' sociodemographic and curricular characteristics.

Brazilian medical student scored higher for caring than for sharing ( $p<0.001 ; d=0.599$ ). Caring scores related to the psychosocial context were significantly higher than scores related to the patient's perspective $(\mathrm{p}<0.001 ; \mathrm{d}=0.797)$. Sharing power and responsibility scores were significantly higher than sharing understanding $(\mathrm{p}<0.001, \mathrm{~d}=0.455)$ (Table 2$)$.

There was no statistical difference among total, sharing and caring scores according to curricular designs ( $p>0.05$ ) (Table 2).

In the regression analysis (Table 3), we observed a positive association between total B-PPOS scores with public schools, female gender, year of medical training, preference for future medical practice in public services, extracurricular activities, as well as a negative association between total B-PPOS scores with the father's educational level and choice to study surgical specialties $(\mathrm{p}<0.05)$.

For caring scores, we found a positive association with public schools, female gender, year of medical training, preference for future medical practice in public services and negative association with the father's educational level $(\mathrm{p}<0.05)$. Sharing B-PPOS scores showed a positive association with public schools, female gender, preference for future medical practice in public services, extracurricular activities, and a negative association with the father's educational level and choice to study surgical specialties $(\mathrm{p}<0.05)$ (Table 3).

\section{DISCUSSION}

This cross-sectional study demonstrates that Brazilian medical students are moderately patient-centered. We know that holistic care and sharing decision-making varies among cultures and social norms ${ }^{7}$. Brazilian cultural and societal values reinforce medical students' attitude in caring more than sharing in the doctor-patient relationship ${ }^{20}$. Furthermore, our students consider the patients' psychosocial context far more than the patients' perspective. For a more person-centered care, beyond the psychosocial context, individual patient's goals and preferences must be at the center of the doctor-patient relationship, which requires a great change in the culture of health care and medical education ${ }^{21,22}$. Understanding care from the patient's perspective can be fostered by educational strategies that value contact with the patients' narratives ${ }^{23}$. 


\section{TABLE 1}

\section{Sociodemographic and curricular characteristics of study population $(n=1,463)$}

\begin{tabular}{|c|c|c|c|c|c|}
\hline \multirow[b]{2}{*}{ Sociodemographic characteristics } & \multirow{2}{*}{$\begin{array}{c}\text { Total } \\
(\mathrm{n}=1, \mathbf{4 6 3} ; \mathbf{1 0 0 . 0} \%)\end{array}$} & \multicolumn{2}{|c|}{ School administration } & \multirow[b]{2}{*}{$\mathbf{X}^{2}$} & \multirow[b]{2}{*}{$\mathbf{p}$} \\
\hline & & $\begin{array}{c}\text { Private } \\
\text { (n }=177 ; 12.1 \%)\end{array}$ & $\begin{array}{c}\text { Public } \\
\text { (n=1,286; } 87.9 \%)\end{array}$ & & \\
\hline Average age, years (SD) & $22.3(3.3)$ & $23.3(4.5)$ & $22.2(3.0)$ & - & $0.06^{\mathrm{a}}$ \\
\hline $\begin{array}{l}\text { Father's and mother's educational level, n (\%) } \\
\text { - Higher education } \\
\text { - High school } \\
\text { - Elementary school } \\
\text { - Missing data }\end{array}$ & $\begin{array}{r}773(52.8) / 932(63.7) \\
469(32.1) / 387(26.4) \\
207(14.1) / 137(9.4) \\
14(1.0) / 7(0.5)\end{array}$ & $\begin{array}{r}75(42.4)+/ 115(65.0)+ \\
66(37.3)+/ 47(26.6)+ \\
32(18.1)+/ 15(8.5) \dagger \\
4(2.3)+/ 0(0.0) \dagger\end{array}$ & $\begin{array}{r}698(54.3)^{*} / 817(63.5)+ \\
403(31.3)+/ 340(26.4)+ \\
175(13.6)+/ 122(9.5)+ \\
10(0.8)+/ 7(0.5)+\end{array}$ & $11.7 / 1.18$ & $0.01 / 0.76$ \\
\hline \multicolumn{6}{|l|}{ Curricular characteristics } \\
\hline $\begin{array}{l}\text { Self-evaluation of curricular design, } \mathrm{n}(\%) \\
\text { - Advanced } \\
\text { - Innovative } \\
\text { - Traditional }\end{array}$ & $\begin{array}{l}448(30.6) \\
710(48.5) \\
305(20.9)\end{array}$ & $\begin{array}{r}89(50.3) \dagger \\
88(49.7) \dagger \\
0(0.0) \dagger\end{array}$ & $\begin{array}{l}359(27.9)^{*} \\
622(48.4) \dagger \\
305(23.7)^{*}\end{array}$ & 67.4 & $<0.01$ \\
\hline Communication-skills activities in curriculum, $\mathrm{n}(\%)$ & $355(24.3)$ & $88(49.7) \dagger$ & $267(20.8)^{*}$ & 71.0 & $<0.01$ \\
\hline Extracurricular activities, $\mathrm{n}(\%)$ & $715(48.9)$ & $107(60.5) \dagger$ & $608(47.3)^{*}$ & 10.8 & $<0.01$ \\
\hline $\begin{array}{l}\text { Future area of specialization, n }(\%) \\
\text { - General practice } \\
\text { - Surgical area } \\
\text { - Surgical clinic area } \\
\text { - Doesn't know } \\
\text { - Other }\end{array}$ & $\begin{array}{r}519(35.5) \\
314(21.5) \\
68(4.6) \\
521(35.6) \\
41(2.8)\end{array}$ & $\begin{array}{r}74(41.8) \dagger \\
37(20.9) \dagger \\
12(6.8) \dagger \\
46(26.0) \dagger \\
8(4.5) \dagger\end{array}$ & $\begin{array}{r}445(34.6) \dagger \\
277(21.5) \dagger \\
56(4.4) \dagger \\
475(36.9)^{*} \\
33(2.6) \dagger\end{array}$ & 11.6 & 0.02 \\
\hline
\end{tabular}

Abbreviations: $\mathrm{n}(\%)$ followed by same symbol does not differ statistically according to Chi-Square test $\left(\mathrm{X}^{2}\right)$.

Mann-Whitney Test. Significance level: $\mathrm{p} \leq 0.05$.

\section{TABLE 2}

\section{Medical students' B-PPOS scores in the total sample and according to curricular design $(n=1,463)$}

\section{B-PPOS}

Total score

Caring domain score

Sharing domain score

Caring subscale score

The patient's perspective subscale $(2,3,7,11,14,17$ Items)

The psychosocial context subscale $(6,13,16$ Items)

Sharing subscale score

Sharing understanding subscale $(5,8,10,18$ Items)

Sharing power and responsibility subscale $(1,4,9,12,15$ Items)

\begin{tabular}{lcc}
$\begin{array}{c}\text { Score (SD) } \\
(\mathbf{n}=1,463)\end{array}$ & $\mathrm{p}^{\mathrm{a}}$ & $\delta^{\mathrm{b}}$ \\
$4.64(0.47)$ & & \\
$5.02(0.45)$ & 0.000 & 0.599 \\
$4.26(0.66)$ & & \\
& & -0.797 \\
$4.70(0.58)$ & 0.000 & \\
$5.68(0.47)$ & & \\
& & -0.455 \\
\hline $.88(0.87)$ & 0.000 & \\
$4.57(0.75)$ & &
\end{tabular}

\section{Curricular design}

\section{B-PPOS}

Total score

Caring domain score

Sharing domain score

$\mathrm{p}^{\mathrm{a}} / \delta^{\mathrm{b}}$

Traditional $(\mathbf{n}=$ Innovative $(\mathbf{n}=$ 305) Score (SD)

$710)$

710) Score (SD)

\section{Advanced $(\mathrm{n}=$}

448) Score (SD)

$\begin{array}{cccc}4.63(0.46) & 4.64(0.48) & 4.65(0.45) & >0.05 \\ 5.01(0.48) & 5.02(0.44) & 5.04(0.45) & >0.05 \\ 4.25(0.65) & 4.27(0.68) & 4.27(0.64) & >0.05 \\ 0.000 / 0.651 & 0.000 / 0.644 & 0.000 / 0.686 & \end{array}$

Abbreviations: B-PPOS: Brazilian Patient-Practitioner Orientation Scale. ${ }^{a}$ Wilcoxon Rank-Sum Test. Significance level: $\mathrm{p}<0.05$. ${ }^{\mathrm{b}} \delta$ (Cliff's Delta): effect size: negligible $(\delta<0.147)$, small $(\delta<0.330)$, medium $(\delta<0.474)$ and large $(\delta \geq 0.474)$. 'Kruskal Wallis Test: scores followed by same symbol do not differ statistically according to Student-Newman-Keuls post hoc test. 


\begin{tabular}{|c|c|c|c|c|c|c|}
\hline \multicolumn{7}{|c|}{$\begin{array}{l}\text { Ordinary Least Squares Regression Analysis for B-PPOS scores and socioc } \\
\text { and curricular characteristics of medical students }(n=1,463)\end{array}$} \\
\hline \multirow[t]{2}{*}{ OLS Analysis Regression ${ }^{a}$} & \multicolumn{2}{|c|}{ Total B-PPOS score } & \multicolumn{2}{|c|}{ Caring B-PPOS score ${ }^{\mathrm{b}}$} & \multicolumn{2}{|c|}{ Sharing B-PPOS score ${ }^{b}$} \\
\hline & \multicolumn{2}{|c|}{$\begin{array}{c}R^{2}=0.089, \text { Adj. } R 2=0.082 \\
F(12,1450)=11.83,{ }^{*} p=<0.001\end{array}$} & \multicolumn{2}{|c|}{$\begin{aligned} & R^{2}=0.043, \text { Adj. } R^{2}=0.035 \\
F= & (12,1450)=5.38,{ }^{*} p=<0.001\end{aligned}$} & \multicolumn{2}{|c|}{$\begin{array}{c}R^{2}=0.083 \text {, Adj. } R^{2}=0.075 \\
F(12,1450)=10.93, p=<0.001\end{array}$} \\
\hline Predictors & $\mathrm{B}(95 \% \mathrm{CI})$ & p $\mathrm{p}$ & $\mathrm{B}(95 \% \mathrm{CI})$ & p & B $(95 \%$ CI $)$ & " p \\
\hline Constant & $4.267(4.08,4.45)$ & $<0.001$ & $4.702(4.51,4.89)$ & $<0.001$ & $3.833(3.57,4.10)$ & $<0.001$ \\
\hline School administration & $0.132(0.06,0.21)$ & $<0.001^{*}$ & $0.100(0.03,0.17)$ & $0.008^{*}$ & $0.165(0.06,0.27)$ & $0.002^{*}$ \\
\hline Self-evaluation of curricular design & $0.014(-0.02,0.05)$ & 0.401 & $0.019(-0.01,0.05)$ & 0.268 & $0.010(-0.04,0.06)$ & 0.683 \\
\hline Gender & $0.180(0.13,0.23)$ & $<0.001^{*}$ & $0.110(0.06,0.16)$ & $<0.001^{*}$ & $0.250(0.18,0.32)$ & $<0.001^{*}$ \\
\hline Father's education level & $-0.029(-0.05,-0.01)$ & $0.003^{*}$ & $-0.021(-0.04,0.002)$ & $0.029^{*}$ & $-0.036(-0.06,-0.008)$ & $0.010^{*}$ \\
\hline Having a religion & $-0.023(-0.09,0.05)$ & 0.542 & $0.013(-0.06,0.08)$ & 0.728 & $-0.058(-0.16,0.04)$ & 0.270 \\
\hline Religious involvement & $-0.015(-0.05,0.02)$ & 0.353 & $-0.003(-0.03,0.03)$ & 0.848 & $-0.027(-0.07,0.02)$ & 0.240 \\
\hline Year of medical training & $0.021(0.00,0.04)$ & $0.019^{*}$ & $\mathbf{0 . 0 1 8}(-0.00,0.03)$ & $0.040^{*}$ & $0.023(-0.00,0.05)$ & 0.063 \\
\hline Communication-skills activities & $0.079(-0.01,0.17)$ & 0.100 & $0.056(-0.04,0.15)$ & 0.236 & $0.102(-0.03,0.23)$ & 0.132 \\
\hline Years of communication-skills activities & $0.024(-0,02,0.07)$ & 0.314 & $0.028(-0.02,0.07)$ & 0.235 & $0.020(-0.05,0.09)$ & 0.557 \\
\hline Future medical practice & $0.053(0.03,0.08)$ & $<0.001^{*}$ & $\mathbf{0 . 0 2 8}(0.00,0.05)$ & $0.019^{*}$ & $\mathbf{0 . 0 7 8}(0.04,0.11)$ & $<0.001^{*}$ \\
\hline Extracurricular activities & $0.068(0.02,0.12)$ & $0.008^{*}$ & $0.046(-0.00,0.10)$ & 0.070 & $\mathbf{0 . 0 8 9}(-0.00,0.15)$ & $0.014^{*}$ \\
\hline Choice for surgical specialties & $-0.028(-0.05,-0.01)$ & $0.008^{*}$ & $-0.017(-0.04,0.003)$ & 0.095 & $\mathbf{- 0 . 0 3 8}(-0.07,0.01)$ & $0.011^{*}$ \\
\hline
\end{tabular}

Abbreviations: B-PPOS: Brazilian Patient-Practitioner Orientation Scale.

OLS: Ordinary Least Squares Regression Analysis. B: unstandardized coefficient. CI: Confidence Interval.Multicollinearity test: Variance Inflation Factor (1.03 $\leq$ VIF $\leq 3.05)$. Regression analysis of subscale B-PPOS scores are describe in Results sections. Significance level: ${ }^{*} \mathrm{p}<0.05$.

Our results show that students share more power and responsibility than understanding. Doctors and students tend to underestimate patients' preference to be fully informed ${ }^{24}$, giving partial information about a diagnosis and limiting the patients' opportunity for reflection ${ }^{25}$. Furthermore, physicians may consider shared decision making a simple philosophical principle or value, and may not necessarily adopt or use it to communicate with patients ${ }^{26}$. Since patients' attitudes and behaviors influence physicians' behavior ${ }^{27}$, patients should be encouraged by physicians to assume an active role as agents for change $\mathrm{e}^{22}$, acquiring the knowledge, skills and confidence to manage their healthcare ${ }^{28,29}$. A truly shared decision approach requires both doctors and patients to be involved in information exchange and treatment decisions $\mathrm{s}^{30,31}$.

Gender is one of the factors that influence the doctor-patient relationship ${ }^{32}$, and the strongest predictor of patient-centered attitudes in our study. Pre-medical school entry factors such as family background and personality have a remarkable influence on the identification of the professional role of women and patient-centeredness ${ }^{33}$.

We know that both male and female medical students have the capacity to improve their patient-centeredness, but evidence shows a gender-dependent communication style influenced by stereotypes. Female physicians and students report more interest in the doctor-patient communication and the patients' psychosocial context, sharing more information with their patients ${ }^{34,35}$. Women also report to be more empathetic, receptive, helpful and sociable than men, whereas men see themselves as robust, overbearing and inhibited. Men tend to establish a relationship of power over the patient, concerned more with medical history and less interested in voluntarily improving their communication skills and attitudes ${ }^{35}$. In view of these gender-differences, effective strategies to implement gender-sensitive communication skills teaching is crucial to enhance the quality of medical training and care, especially among male students ${ }^{32,35}$.

Surprisingly, students from advanced curricular designs did not show more patient-centered attitudes in all domains of the B-PPOS. This could be attributed to the low offer of communication skills activities during medical training. Studies show most medical schools concentrate communication skills activities during preclinical years ${ }^{36}$. It is common knowledge that communication training improves rapport building, shared decision making ${ }^{37}$ and understanding patients' perspectives ${ }^{38}$. Nevertheless, communication-skills learned at the beginning of medical training can be easily forgotten if not reinforced longitudinally throughout medical education ${ }^{39,40,11}$. This might explain the lack of association between patient-centered attitudes among students and the presence of communication-skills activities in their curricula. 
Despite expectations of medical schools to develop humanistic and patient-centered relationships, medical training does not guarantee these desirable learning outcomes ${ }^{7,3}$. Except for the caring domain, we did not observe an influence of the number of years of training among students' attitudes. We believe that informal aspects of medical training such as role models and the hidden curriculum contribute to these results.

Medical schools have traditionally depended on role modeling as part of the informal curriculum, in which physicians' values, attitudes and behaviors influence students' attitudes and career choice ${ }^{41,42}$. Depending on the clinical attributes, teaching skills and personal qualities of the faculty ${ }^{43}$, there may be a negative role model, that resists changes in medical education ${ }^{44}$ and threatens the acquisition and nourishing of humanistic skills and attitudes in future physicians ${ }^{12}$. During medical clerkship, much of the doctor-student socialization occurs outside formal places, where informal experiences become more influential, creating a cascade of events that precludes real changes in medical students' attitude, despite curricular reforms ${ }^{45,3}$.

Additionally, the hidden curriculum also shapes values, roles and identity of medical trainees, at the level of the organizational culture and structure ${ }^{46,47,48}$, creating important barriers to effective and positive role modeling. Emotional neutralization, loss of idealism, acceptance of the hierarchical structure and the adoption of a ritualized professional identity may influence enculturation in medical training $46,47,49$. At the same time, lack of institutional support for faculty development, career development and formal training in teaching methods and reflective practice, associated with work overload ${ }^{50,41}$ lead to a less effective role modeling, especially in clerkship years.

Extracurricular activities are associated with more patient-centered attitudes. Participation in these activities develops empathy, allows reflection and self-development ${ }^{51}$, improves interaction with peers and people of different realities, makes students more engaged in the teaching-learning process $^{52}$ and in the diversity of care ${ }^{53}$. These experiences may contribute to students' interest in the patient's psychosocial, cultural and environmental factors ${ }^{51}$.

The father's higher educational level is a predictor of less patient-centered attitudes. A higher educational level is linked to higher socioeconomic conditions and higher engagement in parental education ${ }^{54}$. Previous studies have also associated physicians who have a high socioeconomic status with more difficulty in sharing information and decision-making with patients ${ }^{55}$.

Our results indicate that the choice to study surgical specialties may predict doctor-centered attitudes. Personal char- acteristics and personality traits may be related to the choice of medical specialty ${ }^{56}$ and can predict cognitive and clinical performance of medical students ${ }^{57}$. Students who intend to choose a surgical specialty demonstrate less social orientations, preference for acute patients, technology-oriented activities and prestige, and are more hospital-oriented than clinical-oriented students ${ }^{58,59}$. These findings suggest that students prone to surgical specialties should receive special support to foster their patient-centered attitudes towards the doctor-patient relationship.

Our study has some limitations. Since we chose an online-based questionnaire to assess students from 21 medical schools of different regions in Brazil, there were difficulties concerning response rates. Despite these issues, we achieved a representative sample of respondents. Although the use of self-reported validated scales facilitates assessing a larger sample of participants, social desirability bias inherent to such instruments may have influenced responses. Another limitation may be related to the fact that PPOS measures attitudes rather than real behavior towards patient-centeredness. Nevertheless, we know that attitudes can predict future physicians' skills and competences ${ }^{60}$. Inferences of causality and temporality are limited by our study design. Despite such limitations, to the best of our knowledge, our study was the first to assess attitudes of students enrolled in different curricular designs, in a multicenter approach.

\section{CONCLUSIONS}

Curricular designs did not predict medical students' attitudes. Being female and attending a public medical school were important predictors of patient-centered attitudes among medical students. Further research should investigate the direct influence of faculty professionalism development programs on patient centered-attitudes among students. Such programs should foster relationship-centered values, in order to establish a proper and safe learning environment.

\section{ACKNOWLEDGMENTS}

We would like to thank the medical schools and students that participated in this study for their willingness and support, believing in the importance of this study for improving doctor-patient relationchip.

\section{REFERENCES}

1. Hirsh DA, Ogur B, Thibault GE, Cox M. 2007. New models of clinical clerkships: "Continuity" as an organizing principle for clinical education reform. N Engl J Med. 356:858866. 
2. Hirsh D, Gaufberg E, Ogur B, Cohen P, Krupat E, Cox M, Pelletier S, Bor D. 2012. Educational outcomes of the Harvard Medical School-Cambridge Integrated Clerkship: a way forward for medical education. Acad Med. 87(5):643650.

3. Gallentine A, Salinas-Miranda AA, Bradley-Klug K, Shaffer-HudkinsE, HinojosaS, Monroe A. 2014. Student perceptions of a patient-centered medical training curriculum. Int J Med Educ. 5:95-102.

4. Coulehan J. 2005. Today's professionalism: engaging the mind but not the heart. Acad Med. 80:892-898.

5. Mader EM, Roseamelia C, Morley CP. 2014. The temporal decline of idealism in two cohorts of medical students at one institution. BMC Med Educ. 14:58.

6. Christianson CE, McBride RB, Vari RC, Olson L, Wilson HD. 2007. From traditional to patient-centered learning: Curriculum change as an intervention for changing institutional culture and promoting professionalism in undergraduate medical education. Acad Med. 82:1079-1088.

7. Haidet P, Dains JE, Paterniti DA, Hechtel L, Chang T, Tseng E, Rogers JC. 2002. Medical student attitudes toward the doctor-patient relationship. Med Educ. 36:568-574.

8. MacLeod A. 2011. Six ways problem-based learning cases can sabotage patient-centred medical education. Acad Med. 86:818-825.

9. Gaufberg E, Hirsh D, Krupat E, Ogur B, Pelletier S, Reiff D, Bor D. 2014. Into the future: Patient-centredness endures in longitudinal integrated clerkship graduates. Med Educ. 48:572-582.

10. Van Dalen J, Kerkhofs E, Van Knippenberg-Van Den Berg BW, Van Den Hout HA, Scherpbier AJ, Van Der Vleuten CPM. 2002. Longitudinal and concentrated communication skills programmes: two dutch medical schools compared. Adv Health Sci Educ. 7(1):29-40.

11. Van Weel-Baumgarten E, Bolhuis S, Rosenbaum M, Silverman J. 2013. Bridging the gap: How is integrating communication skills with medical content throughout the curriculum valued by students? Patient Educ Couns. 90(2):177183.

12. Maheux B, Beaudoin C, Berkson L, Côte $\square$ L, Des Marchais J, Jean P. 2000. Medical faculty as humanistic physicians and teachers: The perceptions of students at innovative and traditional medical schools. Med Educ. 34:630-634.

13. Brazil. 2014. Ministério da Educação. Conselho Nacional de Educação. Câmara de Educação Superior. Diretrizes Curriculares Nacionais do Curso de Graduação em Medicina [Ministry of Education. National Education Council. Camera of Higher Education. National Curricular Guideli- nes of the Undergraduate Course in Medicine]. Resolução CNE/CES 4/2001. Brasília, DF.

14. Lampert JB, Aguillar da Silva RH, Peim GL, Stella RCR, Abdalla IG, Costa NMSC. 2009. Project for the Evaluation of Change Trends in the Undergraduate Course of Brazilian Medical Schools. Rev Bras Educ Med. 33(1):5-18.

15. Krupat E, Rosenkranz SL, Yeager CM, Barnard K, Putnam SM, Inuii TM. 2000. The practice orientations of physicians and patients: the effect of doctor-patient congruence on satisfaction. Patient Educ Couns. 39:49-59.

16. Epstein RM, Franks P, Fiscella K, Shields CG, Meldrum SC, KravitzRL, Duberstein PR. 2005. Measuring patient-centered care in patient-physician consultation: theoretical and practical issues. Soc Sci Med. 61:1516-1528.

17. Pereira CM, Amaral CF, Ribeiro MM, HBMS Paro, Pinto RMC, Reis LET, Silva CHM, Krupat, E. 2013. Cross-cultural validation of the Patient-Practitioner Orientation Scale (PPOS). Patient Educ Couns. 91:37-43.

18. Cochran W. 1986. Sampling techniques. $3^{\text {rd }}$ ed. New York (NY): John Wiley \& Sons.

19. Cliff, N. 1993. Dominance statistics: Ordinal analyses to answer ordinal questions. Psychol Bull. 114:494-509.

20. Ribeiro MM, Krupat E, Amaral CF. 2007. Brazilian medical students' attitudes towards patient-centered care. Med Teach. 29:204-208.

21. English J. 2016. Training doctors for person-centered care. Acad Med. 91:294-296.

22. Hibbard JH. 2017. Patient activation and the use of information to support informed health decisions. Patient Educ Couns. 100:5-7.

23. Easton G. 2016. How medical teachers use narratives in lectures: a qualitative study. BMC Med Educ. 16:3.

24. Moore M. 2009. What do Nepalese medical students and doctors think about patient-centred communication? Patient Educ Couns. 76:38-43.

25. Bernabeo E, Holmboe ES. 2013. Patients, providers, and systems need to acquire a specic set of competencies to achieve truly patient-centered care. Health Aff. 32(2):250258.

26. Karnieli-Miller O, Eisikovits Z. 2009. Physician as partner or salesman? Shared decision-making in real-time encounters. Soc Sci Med. 69:1-8.

27. Street RL, Krupat E, Bell RA, Kravitz, RL, Haidet P. 2003. Beliefs about control in the physician-patient relationship: effect on communication in medical encounters. J Gen Intern Med. 18:609-616.

28. Hibbard JH, Stockard J, Mahoney ER, Tusler M. 2004. Development of the Patient Activation Measure (PAM): con- 
ceptualizing and measuring activation in patients and consumers. Health Serv Res. 39:1005-1026.

29. Alexander JA, Hearld LR, Mittler JN, Harvey J. 2012. Patient-physician role relationships and patient activation among individuals with chronic illness. Health Serv Res. 47(3):1201-1223.

30. Karazivan P, Dumez V, Flora L, Pomey M-P, Grande CD, Ghadiri DP, Fernandez N, Jouet E, Vergnas OL, Lebel P. 2015. The patient-as-partner approach in health care: a conceptual framework for a necessary transition. Acad Med. 90:437-441.

31. Pollard S, Bansback N, Bryan S. 2015. Physician attitudes toward shared decision making: A systematic review. Patient Educ Couns. 98:1046-1057.

32. Bertakis KD. 2009. The influence of gender on the doctor-patient interaction. Patient Educ Couns. 76(3):356-360.

33. Gude T, Vaglum P, Tyssen R, Ekeberg O, Hem E, Rovik JO, Finset K, Gronvold NT. 2005. Identification with the role of doctor at the end of medical school: a nationwide longitudinal study. Med Educ. 39:66-74.

34. Roter DL, Hall JL. 2004. Physician gender and patient-centered communication: a critical review of empirical research. Annu Rev Public Health. 25:497-519.

35. Loffler-Stastka H, Seitz T, Billeth S, Pastner B, Preusche I, Seidman C. 2016. Significance of gender in the attitude towards doctor-patient communication in medical students and physicians. Wien Klin Wochenschr. 128(17):663-668.

36. Kalet A, Pugnaire MP, Cole-Kelly K, Janicik R, Ferrara E, Schwartz MD, Lipkin M, Lazare, A. 2004. Teaching communication in clinical clerkships: models from the Macy Initiative in Health Communications. Acad Med. 79(6):511-520.

37. Yedidia MJ, Gillespie CC, Kachur E, Schwartz MD, Ockene J, Chepaitis AE, Snyder CW, Lazare A, Lipkin M. 2003. Effect of communications training on medical student performance. JAMA.290:1157-1165.

38. Mukohara K, Kitamura K, Wakabayashi H, Abe K, Sato J, Ban N. 2004. Evaluation of a communication skills seminar for students in a Japanese medical school a non-randomized controlled study. BMC Med Educ. 4:24.

39. Prislin MD, Giglio M, Lewis EM, Ahearn S, Radecki S. 2000. Assessing the acquisition of core clinical skills through the use of serial standardized patient assessments. Acad Med. 75:480-483.

40. Woloschuk W, Harasym PH, Temple W. 2004. Attitude change during medical school: a cohort study. Med Educ. 38:522-534.

41. Cruess SR, Cruess RL, Steinert Y. 2008. Role modelling-making the most of a powerful teaching strategy. BMJ. 336:718-721.
42. Passi V, Johnson N. 2016. The hidden process of positive doctor role modelling. Med Teach. 38:700-707.

43. Passi V, Johnson S, Peile E, Wright S, Hafferty F, Johnson N. 2013. Doctor Role Modelling in Medical Education. BEME Guide No. 27. Med Teach. 35:1422-1436.

44. Paice E, Heard S, Moss F. 2002. How important are role models in making good doctors? Br Med J. 325(7366):707710.

45. Mahood SC. 2011. Medical education: beware the hidden curriculum. Can Fam Physician. 57(9):983-985.

46. Lempp H, Seale C. 2004. The hidden curriculum in undergraduate medical education: qualitiative study of medical students' perceptions of teaching. BMJ.329(7469):770-773.

47. Gaufberg EH, Batalden M, Sands R, Bell SK. 2010. The hidden curriculum: What can we learn from third-year medical student narrative reflections? Acad Med. 85:1700-1716.

48. Cruess RL, Cruess SR, Boudreau JD, Snell L Steinert Y. 2015. A schematic representation of the professional identity formation and socialization of medical students and residents: A guide for medical educators. Acad Med. 90:718-725.

49. Martimianakis MAT, Michalec B, Lam J, Cartmill C, Taylor JS, Hafferty FW. 2015. Humanism, the hidden curriculum, and educational reform: A scoping review and thematic analysis. Acad Med. 90(11):S5-13.

50. Seabrook MA. 2003. Medical teachers'concerns about the clinical teaching context. Med Educ. 37:213-222.

51. Ahrweiler F, Neumann M, Goldblatt H, Hahn EG, Scheffer C. 2014. Determinants of physician empathy during medical education: hypothetical conclusions from an exploratory qualitative survey of practicing physicians. BMC Med Educ. 14:122

52. Torres AR, Oliveira GM, Yamamoto FM, Lima MCP. 2008. Academic Leagues and medical education: contributions and challenges. Interface Comunic Saúde Educ. 12:713720.

53. Niu NN, Syed ZA, Krupat E, Crutcher BN, Pelletier SR, Shields HM. 2012. The impact of cross-cultural interactions on medical students' preparedness to care for diverse patients. Acad Med. 87:1530-1534.

54. Cabrera NJ, Shannon JD, Tamis-LeMonda C. 2007. Fathers' influence on their children's cognitive and emotional development: From toddlers to pre-K. Appl Develop Sci. 11(4):208-213.

55. Tsimtsiou Z, Benos A, Garyfalos A, Hatzichristou D. 2012. Predictors of physicians' attitudes towards sharing information with patients and addressing psychosocial needs: a cross sectional study. Health Commun. 27:257-263. 
56. Zimny GH, Senturia AG. 1973. Medical specialty counseling: A survey. J Med Educ. 48:336-342.

57. Taber B, Hartung P, Borges N. 2011. Personality and values as predictors of medical speciality choice. J Voc Behav. 78:202-209.

58. Maiorova T, Stevens F, Scherpbier A, Van der Zee J. 2008. The impact of clerkships on students' specialty preferences: what do undergraduates learn for their profession? Med Educ. 42:554-562.

59. Scott IM, Matejcek AN, Gowans MC, Nut Diet M, Wright BJ, Brennels FR. 2008. Choosing a career in surgery: factors that influence Canadian medical students' interest in pursuing a surgical career. Can J Surg. 51(5):371-377.

60. Ajzen I, Fishbein M. 2005. The influence of attitudes on behavior. In: Albarracín D, Johnson BT, Zanna MP, Eds. Handbook of attitudes and attitudes change. Hillsdale, (NJ): Erlbaum; p. 173-221.

\section{CONTRIBUTIONS}

Claudia Pereira gave substantial contributions to the conception, design of the work; acquisition, analysis and interpretation of data for the work, drafting and revising it critically for important intellectual content; gave final approval of the version to be published and agreement to be accountable for all aspects of the work in ensuring that questions related to the accuracy or integrity of any part of the work are appropriately investigated and resolved.

Filipe Bernardes and Amanda Giroldo gave substantial contributions to the acquisition, analysis and interpretation of data, drafting the work and revising it critically for important intelectual content.
Carlos Silva gave substantial contributions to the conception, design of the work; gave agreement to be accountable for all aspects of the work in ensuring that questions related to the accuracy or integrity of any part of the work were appropriately investigated and resolved, and also gave final approval of the version to be published.

Helena Paro gave substantial contributions to the conception, design of the work; acquisition, analysis and interpretation of data for the work, drafting and revising it critically for important intellectual content; gave final approval of the version to be published and agreement to be accountable for all aspects of the work in ensuring that questions related to the accuracy or integrity of any part of the work are appropriately investigated and resolved.

\section{CONFLICT OF INTERESTS}

The authors report no declarations of conflict of interests.

\section{POSTAL ADDRESS}

Praça Clarimundo Carneiro, 68 - apto 68

Centro - Uberlândia

CEP 38400-154 - MG

E-mail: claudia.masp@hotmail.com 